\section{A FIELD LAID DOWN TO PERMANENT GRASS.}

A VALUABLE paper, by Sir J. B. Lawes, on the A history of a field laid down to permanent grass, has been reprinted, by Messrs. Spottiswoode, from the Journal of the Royal Agricultural Society of England. The field in question forms part of the Rothamsted estate, and was laid down to permanent grass nearly thirty years ago, by Dr. Gilbert, to whom it was let in 1856 . It has been mown for hay every year from the commencement; and in the present pamphlet Sir J. B. Lawes gives full particulars as to the economical results, the constituents supplied in the manures and removed in the crops, the changes within the soil in the formation of the meadow, and the botany of the meadow. The following are his summary and general conclusions :-

(I) By the judicious employment of manures, both natural and artificial, arable land has been converted into permanent grass, not only without loss, but with some profit to the tenant.

(2) The important constituents, nitrogen and phosphoric acid, were supplied in the manures in larger quantities than they were removed in the crops; but potash in only about the same quantity as it was removed.

(3) The application of dung, not only compensates for much of the exhaustion from the removal of hay, but it has a beneficial influence on the botanical character of the herbage.

(4) Although the grass has been mown every year for nearly thirty years, there has been a considerable accumulation of fertility within the soil.

(5) Analysis has shown that there has been an increase of nitrogen in the surface-soil, beyond that which could be explained by excess supplied in manure over that removed in crops, and by the combined nitrogen coming down in rain, and the minor deposits from the atmosphere. Part, if not the whole, of this increase is probably derived from the subsoil by deeply-rooted plants, which afterwards leave a nitrogenous residue within the surface-soil. Or, possibly, some of it may have its source in the free nitrogen of the atmosphere, brought into combination within the soil, under the influence of micro-organisms, or other low forms.

(6) In laying down arable land to permanent grass, especially if hay is to be removed, it is essential to supply, not only nitrogenous, but an abundance of mineral manures, and especially of potash, a large quantity of which is removed in the crops, and must be returned. When the grass is not mown, but fed, the exhaustion is much less, but it is greater when consumed for the production of milk than when for that of store or fattening increase.

\section{THE TOTAL ECLIPSE OF DECEMBER 22.}

MISFORTUNE has attended the double expedition I sent by the Royal Astronomical Society to observe the total eclipse of December 22. In Africa observations were made impossible by bad weather. Observations were secured off the coast of French Guiana, but at a cost which is deeply to be deplored-the death of Father Perry.

The telegram received from Demerara is as follows:"104 corona American Perry dead dysentery." With regard to the part of this telegram which needs explanation, the Times of January 6 says:- " 104 is resolvable into the factors 2,4 , and 13 , of which the first number means that the weather was only moderately good; the second that successful exposures were made with the Abney 4-inch lens, but that the development was not carried out, owing either to unfavourable climatic conditions, or possibly to the illness of Father Perry; and the third, that successful photographs were obtained with the 2o-inch mirror, but again the development was not completed. The words corona American signify most probably that the corona was of the same form as that seen on January I, I 889, when a total eclipse was successfully observed in California, and the form was then that now generally ascribed to a period of minimum sun-spots, elongated at the sun's equator and radial but short at the poles."

\section{NOTES.}

THE list of those who received New Year's honours and appointments included Brigade-Surgeon George King, F.R.S., Bengal Medical Service, Superintendent of the Royal Botanical Gardens, Calcutta. He has been made Companion of the most eminent order of the Indian Empire.

THE seventy-second anniversary of the Institution of Civil Engineers occurred last Thursday, when a revised list of the members of all classes showed that the numbers on the books amounted to 5904, representing an increase of $3 \frac{1}{3}$ per cent. in the past twelve months.

THE Institution of Electrical Engineers will hold the first meeting of the current term this evening, when the President, Dr. John Hopkinson, F.R.S., will deliver his inaugural address.

THE annual general meeting of the Royal Meteorological Society will be held at 25 Great George Street, Westminster, on Wednesday, the $15^{\text {th }}$ inst., at 7.15 p.m., when the Report of the Council will be read, the election of Officers and Council for the ensuing year will take place, and the President (Dr. W. Marcet, F.R.S.) will deliver an address on "Atmospheric Dust," which will be illustrated by a number of lantern slides.

The Mining Journal is to be congratulated on the very admirable portait of Dr. Archibald Geikie which appeared in its issue of December 28. The portrait was accompanied by a short but very good account of Dr. Geikie's life and labours.

Dr. Raoul Gautier has been appointed Professor of Astronomy at the University of Geneva, and has at the same time been made director of the Observatory. His father, Colonel E. Gautier, retains his connection with the latter establishment, with the title of honorary director.

THE Professorship of Agriculture and Rural Economy at the Royal Agricultural College, Cirencester, vacant by the resignation of Prof. McCracken, has been conferred upon an old student and gold medallist of the College, Mr. James Muir.

THE arrangements of the Royal Botanic Society for 1890 include exhibitions of spring flowers on March 26 and April 23; summer exhibitions of plants, flowers, and fruit, on May 14 and June II; and an evening fête and exhibition on July 2. Botanical lectures will be given on May 9, 16, 23, and 30, and on June 6 and 13 . These lectures will be free to all visitors in the Gardens.

ON Thursday, January 16, Prof. R. Meldola, F.R.S., will begin a course of twelve special evening lectures at the Finsbury Technical College, on coal-tar products. The object of the course is to describe the technology of the raw materials manu factured from the tar. The theoretical treatment will serve as a general introduction to the chemistry of the aromatic compounds. A syllabus can be had on application to the College. 